\title{
Evaluation of Different Mandibular Measurements by Cone Beam Computed Tomography as A Forensic Age \& Gender Determination Tools.
}

\author{
Gehad S. Abd Elsalam ${ }^{1 *}$, Ossama S. El-Shal ${ }^{2}$, Afaf A. Shaaban ${ }^{3}$
}

Codex : 54/1910

azhardentj@azhar.edu.eg

http://adjg.journals.ekb.eg

DOI: $10.21608 /$ adjg.2019.7749.1098

\begin{abstract}
Purpose: The aim of the study was to analyze and assess the different dimensions of the major mandibular land marks using CBCT and also to analyze whether these parameters can be used in sexual dimorphism for forensic identification. Material and methods: retrospective study: included 102 patients (51 males and 51 females), with age group ranging between 20 and 50 years obtained from the outpatient, department of oral medicine, periodontology, oral diagnosis and radiology, Faculty of Dental Medicine for girls, Al-Azhar University. Patients were divided into groups and sub groups according to gender and age. CBCT scan was performed on all the patients, and the data obtained were reconstructed for 3D viewing. After obtaining 3D-CT scan, a total of twelve mandibular measurements, i.e., (Rt, Lt) gonial angle (G-angle), bimental breadth, bigonial width, bicondylar breadth (BIC-Br), and bicoroniod breadth, Rt, Lt mental index, (Rt, Lt) height of mandible from mental foramen, maximum mandibular length were measured and mandibular index calculated; collected data were analyzed using SPSS statistical analysis program by Student's t-test. Results: The result of the study showed that out of nine parameters, Rt gonial angle, Rt mental index, Rt and Lt height of mandible from mental foramen, bigonial width, bicondylar breadth, bicoroniod breadth, maximum mandibular length and mandibular index showed a significant statistical difference $(\mathrm{P}<0.05)$, with overall accuracy of $83.7 \%$ for males and $81.3 \%$ for females. Conclusion: Mandibular parameters obtained through CBCT can aid in sex identification with much higher accuracy.
\end{abstract}

\section{INTRODUCTION}

Identification of an individual is important and the reasons for attempting identification are manifold. It plays a significant role in homicides, loss of lives owing to natural calamities, wars, terrorist attacks, major road traffic accidents etc.

\section{KEYWORDS}

Sex determination, mandibular

measurements, CBCT, Forensic

dentistry, sexual dimorphism.

- Paper extracted from master thesis titled "Sex Determination of the Egyptian Population Using Mandibular CBCT Scans"

1. *Demonstrator in Oral Medicine, Periodontology, Oral Diagnosis and Dental Radiology Department Faculty of Dental Medicine for Girls, Al-Azhar University.Email: gsamy1633@gmail.com

2. Professor, Oral Medicine, Periodontology, Diagnosis and Radiology department, Faculty of Dental Medicine for Girls, Al-Azhar University

3. Lecturer of Forensic Medicine and Clinical Toxicology, Faculty of Medicine for Girls, Al-Azhar University. 
Age and Gender determination is an important component of personal identification. Although osseous structures of the skull like foramen magnum (1), frontal and maxillary sinuses, have been used in gender determination, the preservation of these structures after the death of an individual is less likely ${ }^{(2)}$.

The mandible is one of the most indestructible parts of the body and upon exposure to physical injury and putrefaction, it outlasts other tissues. The preservation of mandible in ancient human relics for centuries attests to this fact. The foramina of the mandible and mandibular canal have a relatively constant location in the mandible throughout the life of an individual.

Computed tomography (C.T) is a three-dimensional imaging modality It has been demonstrated to be effective in assessing the size and location of the structures like mental foramen and mandibular canal in forensic and anthropologic studies.

CBCT is a more recently introduced $3 \mathrm{D}$ imaging modality that offers undistorted information of the maxillofacial anatomy with significantly lower effective radiation dose and higher spatial resolution than computed tomography $(\mathrm{CT})^{(3)}$.

The applications extend from implantology, oral and maxillofacial surgeries, temporomandibular joint assessment, endodontics, orthodontics, periodontics, sinus imaging, temporal bone/lateral skull and skull base studies ${ }^{(4,5)}$. This give Certain studies on 3D reconstruction ${ }^{(6)}$, bite-mark analysis ${ }^{(7)}$, age estimation ${ }^{(8)}$, person Identification ${ }^{(9)}$ and anthropological assessment ${ }^{(10)}$

\section{MATERIAL AND METHODS}

This retrospective study included 102 CBCT scans collected from the database of patients affiliated to Oral radiology center, from July 2017 to December 2018. The study was approved by the research ethical committee of Faculty of Dentistry, Al-Azhar University for Girls.
The scans were obtained from a Planmeca ProMax Mid 3D machine (Imaging Sciences, Finland) under fixed parameters (90 KVP, $12 \mathrm{~mA}$, and $400 \mu \mathrm{m}$ in 18.288 seconds) Field of View (FOV) was adjusted separately for each human mandible.

The inclusion criteria included both sexes of adult patients (51 males and 51 female), dentate patients, and aged between 20 and 50 years. Patients divided into groups according to sex and each group subdivided into three subgroups according to age. Patients with any evidence of any mandibular pathology such as fractures, impacted teeth, cysts, tumors, osteomyelitis in the mandible excluded from the study. And also, images with developmental abnormalities of the mandible like aplasia, bone and joints disorders. Patients with history of head trauma, congenital craniofacial abnormalities, orthognathic surgery and facial asymmetry excluded also from study.

\section{i. Tomographic measurements:}

Tomographic measurements were made using The Digital Image Communication in Medicine (DICOM) Romexis viewer (4.4.2.R) 2016 software was used to analyze the reconstructed image sections. With the use of ruler tool from software (4.4.2.R) linear measurements were recorded. The observers primarily detected the $3 \mathrm{D}$ locations of gonion, gnathion, condylion, mental foramen and coronoid process.

Then, twelve different measurements were taken to detect the human sex ${ }^{(11,12)}$. The first six measurements were obtained from 3D sagittal view and they were gonial angle (GA) on both sides, mental index on both sides and height of mandible from mental foramen on both sides. Another four measurements were obtained from 3D coronal view and they were bicondylar breadth, bicoroniod breadth, bigonial width and bimental breadth. The last measurement obtained from 3D axial view was maximum mandibular length (MML). Then mandibular index was calculated according to Thomson criteria which equal (Length of lower jaw / Bicondylar breadth'100). 
The junction of the posterior and lower borders of the mandible forms (GA). The thickness of the mandibular lower cortex forms mental index. Bicondylar breadth $(\mathrm{BicBr})$ is between most outer points of head of condyles. Bicoroniod breadth is Distance between two coronoids laterally. bigonial width is determined by the most lateral points of both gonia. Bimental breadth is Distance between the inner margins of the two mental foraminas. Maximum mandibular length (MML) which is the Straight distance from posterior margins of the chin to tangent drawn at two gonias.

The scans were selected and assessed by two Oro maxillofacial radiologists with four years' experience and both were calibrated prior conducting the experiment. After 14 days, Values were measured again.

\section{ii. Statistical analysis:}

Values were presented as mean and stander deviation (SD) values. Data were explored for normality using Kolmogorov- Smirnov test of normality. The results of Kolmogorov- Smirnov test indicated that most of the data were normally distributed (parametric data), therefore, independent $\mathrm{T}$ test was used for two group comparison. On way analysis of variance (ANOVA) test was used to compare more than two group. This was followed by Tukey's post hoc test when the difference was found to be significant.

The significance level was to set at $\mathrm{p}<0.05$. Statistical analysis was performed with SPSS 18.0 (Statistical package for Scientific studies, SPSS, Inc., Chicago, IL, USA) for windows.

\section{RESULTS}

\section{I- Retrospective study: 1- A. Demographic data of the patients:}

The highest mean value was found in (Group B/ Males) group, while the least mean value was found in (Group A/ Females) group. There was no statistically significant difference between (Group
A/ Females) and (Group B/ Males) groups where $(p=0.617)$.

\section{B. comparison between group A (females) and group B (males) in all mandibular measurements_}

The highest mean value was found in (Group B/ Males) group except for left gonial angle was higher in (Group A/ Females). This was a highly statistically significant $(\mathrm{p}<0.0001)$ in Bicondylar breadth, Bicoroniod breadth, bigonial width, Rt mental index, MML, Mandibular index, Rt height of mandible from mental foramen and statistically significant $(\mathrm{p}<0.005)$ in both Rt gonial angle and Left height of mandible from mental foramen as shown in table (1).

Table (1): The significance of each parameter in relation to sex variable.

\begin{tabular}{|c|c|c|c|c|c|}
\hline \multirow{3}{*}{ Variables } & \multicolumn{5}{|c|}{ Total } \\
\hline & \multicolumn{2}{|c|}{ Group A/ Female } & \multicolumn{2}{|c|}{ Group B/ Male } & \multirow{2}{*}{ p-value } \\
\hline & Mean & SD & Mean & SD & \\
\hline Age & 33.75 & 8.18 & 34.55 & 8.03 & $0.617 \mathrm{~ns}$ \\
\hline Bi-mental breadth & 41.75 & 1.81 & 42.57 & 2.44 & $0.057 \mathrm{~ns}$ \\
\hline Mandibular index & 58.70 & 2.81 & 61.55 & 3.54 & $<0.001 *$ \\
\hline RT mental index & 3.70 & 0.34 & 4.187 & 52.06 & $<0.001 *$ \\
\hline Lt mental index & 4.02 & 0.55 & 4.153 & 64.81 & $0.154 \mathrm{~ns}$ \\
\hline MML & 61.59 & 1.93 & 68.54 & 4.15 & $<0.001 *$ \\
\hline RT Gonial angle & 138.38 & 5.02 & 140.91 & 2.94 & $0.002 *$ \\
\hline LT Gonial angle & 138.82 & 5.45 & 138.78 & 3.45 & $0.968 \mathrm{~ns}$ \\
\hline Bigonial width & 86.94 & 4.65 & 96.75 & 5.07 & $<0.001 *$ \\
\hline Bicondylar breadth & 105.20 & 3.91 & 111.49 & 4.39 & $<0.001 *$ \\
\hline Bicoroniod breadth & 88.74 & 2.91 & 96.61 & 3.09 & $<0.001 *$ \\
\hline $\begin{array}{l}\text { RT height of } \\
\text { mandible from } \\
\text { mental foramen }\end{array}$ & 28.36 & 2.18 & 31.21 & 2.81 & $<0.001 *$ \\
\hline $\begin{array}{l}\text { LT height of } \\
\text { mandible from } \\
\text { mental foramen }\end{array}$ & 29.03 & 3.56 & 30.63 & 2.43 & $0.009 *$ \\
\hline
\end{tabular}

*; highly significant $(p<0.01) \mathrm{s}$; significant $(p<0.05)$ $n s ;$ non-significant $(p>0.05)$ 
C. Comparison between group A (females) and group $B$ (males) in all mandibular measurements from age 20 to 30 year:

The highest mean value was found in (Group B/ Males) while the least mean value was found in (Group A/ Females) group. This was a highly statistically significant $(\mathrm{p}<0.0001)$ in Bicondylar breadth, Bicoroniod breadth, bigonial width, Rt height of mandible from mental foramen and statistically significant $(\mathrm{p}<0.005)$ in Rt mental index, MML, Rt gonial angle and Left height of mandible from mental foramen as shown in table (2).

Table (2): comparison between group A (females) and group $B$ (males) in all mandibular measurements from age 20 to 30 year.

\begin{tabular}{|c|c|c|c|c|c|}
\hline \multirow[b]{2}{*}{ Variables } & $\begin{array}{c}\text { Age } \\
(20-29)\end{array}$ & \multirow[b]{2}{*}{$\begin{array}{c}\text { Group } \\
\text { B1/ } \\
\text { Male }\end{array}$} & \multirow[b]{2}{*}{ p-value } & \multirow[b]{2}{*}{$\mathrm{SD}$} & \\
\hline & $\begin{array}{l}\text { Group } \\
\text { A1/ } \\
\text { Female }\end{array}$ & & & & \\
\hline Age & 24.65 & 25.47 & $0.434 \mathrm{~ns}$ & 3.14 & 2.92 \\
\hline $\begin{array}{l}\text { Bi-mental } \\
\text { breadth }\end{array}$ & 41.67 & 42.75 & $0.176 \mathrm{~ns}$ & 1.5 & 2.86 \\
\hline $\begin{array}{l}\text { Mandibular } \\
\text { index }\end{array}$ & 60.22 & 60.27 & $0.972 \mathrm{~ns}$ & 2.97 & 4.89 \\
\hline RT mental index & 3.75 & 4.14 & $0.014^{*}$ & 0.4 & 0.47 \\
\hline Lt Mental index & 4.2 & 4.24 & $0.847 \mathrm{~ns}$ & 0.79 & 0.35 \\
\hline MML & 62.43 & 67.27 & $0.003^{*}$ & 2.07 & 5.95 \\
\hline RT Gonial angle & 137.09 & 141.05 & $0.015^{*}$ & 5.56 & 3.07 \\
\hline LT Gonial angle & 137.36 & 138.8 & $0.447 \mathrm{~ns}$ & 6.44 & 4.26 \\
\hline Bigonial Width & 85.4 & 97.26 & $<0.001^{*}$ & 4.64 & 4.76 \\
\hline $\begin{array}{l}\text { Bicondylar } \\
\text { breadth }\end{array}$ & 103.81 & 111.66 & $<0.001 *$ & 4.03 & 5.42 \\
\hline $\begin{array}{l}\text { Bicoroniod } \\
\text { breadth }\end{array}$ & 87.85 & 95.04 & $<0.001^{*}$ & 3.03 & 3.44 \\
\hline $\begin{array}{l}\text { RT Height of } \\
\text { mandible from } \\
\text { mental foramen }\end{array}$ & 26.86 & 30.51 & $<0.001 *$ & 1.8 & 3.31 \\
\hline $\begin{array}{l}\text { LT Height of } \\
\text { mandible from } \\
\text { mental foramen }\end{array}$ & 26.96 & 30.38 & $0.002 *$ & 3.32 & 2.69 \\
\hline
\end{tabular}

$*$; highly significant $(p<0.01) s$; significant $(p<0.05)$ $n s$; non-significant $(p>0.05)$
D. Comparison between group A (females) and group B (males) in all mandibular measurements from 30 < age to 40 year:

The highest mean value was found in (Group B/ Males) except for gonial angle and left height of mandible from mental foramen was found higher in (Group A/ Females) group. This was a highly statistically significant $(\mathrm{p}<0.0001)$ in Bicondylar breadth, Bicoroniod breadth, Bigonial width, Mandibular index, MML, Rt mental index and statistically significant $(\mathrm{p}<0.005)$ in Lt mental index and Lt gonial angle as shown in table (3).

Table (3): Comparison between group A (females) and group $B$ (males) in all mandibular measurements from $30<$ age to 40 year.

\begin{tabular}{|c|c|c|c|c|c|}
\hline \multirow{2}{*}{ Variables } & $\begin{array}{c}\text { Age (30 } \\
-39) \text { ) }\end{array}$ & \multirow[b]{2}{*}{$\begin{array}{c}\text { Group } \\
\text { B2/ } \\
\text { Male }\end{array}$} & \multirow[b]{2}{*}{ p-value } & \multirow{2}{*}{ SD } & \\
\hline & $\begin{array}{l}\text { Group } \\
\text { A2/ } \\
\text { Female }\end{array}$ & & & & \\
\hline Age & 33.06 & 34.24 & $0.137 n s$ & 2.16 & 2.33 \\
\hline $\begin{array}{c}\text { Bi-mental } \\
\text { breadth }\end{array}$ & 41.94 & 42.25 & $0.667 n s$ & 1.87 & 2.22 \\
\hline $\begin{array}{l}\text { Mandibular } \\
\text { index }\end{array}$ & 58.15 & 62.7 & $<0.001 *$ & 1.67 & 3.16 \\
\hline RT mental index & 3.57 & 4.26 & $<0.001 *$ & 0.21 & 0.4 \\
\hline Lt mental index & 3.84 & 4.13 & $0.024 *$ & 0.3 & 0.4 \\
\hline MML & 60.86 & 68.77 & $<0.001 *$ & 1.13 & 3.64 \\
\hline RT Gonial angle & 140.77 & 140.23 & $0.675 n s$ & 4.28 & 3.08 \\
\hline LT Gonial angle & 141.55 & 138.02 & $0.006^{*}$ & 4.09 & 2.68 \\
\hline Bigonial width & 85.37 & 97.29 & $<0.001 *$ & 4.4 & 5.92 \\
\hline $\begin{array}{l}\text { Bicondylar } \\
\text { breadth }\end{array}$ & 105.15 & 109.94 & $0.001 *$ & 3.11 & 4.18 \\
\hline $\begin{array}{c}\text { Bicoroniod } \\
\text { breadth }\end{array}$ & 88.45 & 96.16 & $<0.001 *$ & 2.99 & 2.37 \\
\hline $\begin{array}{l}\text { RT height of } \\
\text { mandible from } \\
\text { mental foramen }\end{array}$ & 29.74 & 31.46 & $0.050 \mathrm{~ns}$ & 2.33 & 2.53 \\
\hline $\begin{array}{l}\text { LT height of } \\
\text { mandible from } \\
\text { mental foramen }\end{array}$ & 31.74 & 30.5 & $0.121 n s$ & 2.6 & 1.88 \\
\hline
\end{tabular}

*; highly significant $(p<0.01) s$; significant $(p<0.05)$ $n s$; non-significant ( $p>0.05)$ 


\section{E. comparison between group A (females) and group B (males) in all mandibular measurements from 40 < age to 50 year:}

The highest mean value was found in (Group B/ Males) while the least mean value was found in (Group A/ Females) group. This was a highly statistically significant $(\mathrm{p}<0.0001)$ in Bicondylar breadth, Bicoroniod breadth, Bigonial width, Mandibular index, MML, Rt height of mandible from mental foramen and statistically significant $(\mathrm{p}<0.005)$ in Rt mental index, Rt gonial angle and Lt height of mandible from mental foramen as shown in table (4).

Table (4): Comparison between group A (females) and group $B$ (males) in all mandibular measurements from $40<$ age to 50 year.

\begin{tabular}{|c|c|c|c|c|c|}
\hline Variables & $\begin{array}{c}\text { Age } \\
\left(\begin{array}{c}40- \\
50)\end{array}\right. \\
\text { Group } \\
\text { A3/ } \\
\text { Female }\end{array}$ & $\begin{array}{c}\text { Group } \\
\text { B3/ } \\
\text { Male }\end{array}$ & p-value & SD & \\
\hline Age & 43.53 & 43.94 & $0.599 \mathrm{~ns}$ & 2.07 & 2.44 \\
\hline Bi-mental breadth & 41.64 & 42.71 & $0.167 n s$ & 2.11 & 2.3 \\
\hline Mandibular index & 57.73 & 61.67 & $<0.001 *$ & 3.05 & 1.44 \\
\hline RT mental index & 3.78 & 4.16 & $0.316 \mathrm{~ns}$ & 0.36 & 0.39 \\
\hline Lt mental index & 4.02 & 4.09 & $0.593 n s$ & 0.4 & 0.36 \\
\hline MML & 61.47 & 69.58 & $<0.001 *$ & 2.17 & 1.5 \\
\hline RT Gonial angle & 137.26 & 141.46 & $0.003^{*}$ & 4.52 & 2.71 \\
\hline LT Gonial angle & 137.54 & 139.52 & $0.168 n s$ & 4.76 & 3.28 \\
\hline Bigonial width & 90.04 & 95.7 & $<0.001 *$ & 3.37 & 4.56 \\
\hline $\begin{array}{c}\text { Bicondylar } \\
\text { breadth }\end{array}$ & 106.64 & 112.87 & $<0.001 *$ & 4.21 & 2.97 \\
\hline $\begin{array}{l}\text { Bicoroniod } \\
\text { breadth }\end{array}$ & 89.91 & 98.62 & $<0.001 *$ & 2.43 & 2.29 \\
\hline $\begin{array}{c}\text { RT height of } \\
\text { mandible from } \\
\text { mental foramen }\end{array}$ & 28.47 & 31.66 & $<0.001 *$ & 1.33 & 2.55 \\
\hline $\begin{array}{c}\text { LT height of } \\
\text { mandible from } \\
\text { mental foramen }\end{array}$ & 28.39 & 31.01 & $0.012 *$ & 3.01 & 2.73 \\
\hline
\end{tabular}

*; highly significant $(p<0.01)$ s; significant $(p<0.05)$ $n s ;$ non-significant $(p>0.05)$

\section{DISCUSSION}

Gender Identification from remains of human skeletons is an important forensic procedure. It has been reported that gender can be determined with accuracy of $100 \%$ if entire skeleton is available. A total of $98 \%$ accuracy can be achieved from both pelvis and the skull ${ }^{(13)}$.

In the current study we tried to investigate whether the parameters of mandible can be used to sexual dimorphism of an individual for forensic identification in Egyptians using twelve mandibular CBCT measurements.

The present study of sexual dimorphism was used 102 scans ranged from 20 to 50 years old. Another study also used the full mandibular projections of 330 African individuals ranging from 6 to 60 years (11). While another study was used the mandibular scans of 159 collected from a Brazilian population ranging from 18 to 60 years old ${ }^{(12)}$. Such age range was selected because all skull bones had reached almost complete puberty with minimal growth changes.

Mandible selection in our study as the skull bone of choice due to its high density according to previous study ${ }^{(12)}$. Other skull bones were used for the purpose of sexual prediction as described in previous study ${ }^{(14)}$ which used a $3 \mathrm{D}$ reconstructed CT images of the curvature of the best fit-circle of the greater sciatic notch and while there a study was used maxillary frontal sinuses ${ }^{(16)}$. Another study was ${ }^{(18)}$ used victims' cranial base for dimorphism.

Measurements was included in our study following other study protocol for eight different mandibular measurements ${ }^{(12)}$. Those were gonial angle (GA), bi- gonial breadth (BigBr), bi-condylar breadth (BicBr), bimental breadth, bicoroniod breadth, right mental index, left mental index, right height of mandible from mental foramen, left height of mandible from mental foramen, maximum mandibular length were measured and mandibular index calculated. 
The last nine measurements of the current study (bimental breadth, bicoroniod breadth, right mental index, left mental index, right height of mandible from mental foramen, left height of mandible from mental foramen, maximum mandibular length was measured and mandibular index) were added to this research as a new entity in response to the fact that there is a musculature difference between males and females. That would reflect on the degree of skeletal growth and development in a way that allowed us to markedly differentiate between sexes.

Previous study was used six mandibular measurements that were (RL), (GA), minimum ramus breadth (MRBr), (GGL), (BigBr), and (BicBr) on Africans for sexual identification ${ }^{(11)}$. Similarly, another study was used a specific mandibular ramus measurements namely coronoid height, projective height, condylar height, and maximum breadth and minimum breadth of ramus on Brazilians ${ }^{(15)}$. Also, (MRBr) was excluded from current study because it proved dimorphism in one out of the two analysis tests used in their studies which meant weak significance $^{(11,12)}$.

The CBCT imaging technique was used according to previous study ${ }^{(17)}$. in the current study due to its unique capabilities of reconstructing a 3D volume with no magnification and minimum distortion as described by another study ${ }^{(19)}$. Scans of CBCT were produced through harmonious steps unlike spiral CT was used in other study which exposed the patients to higher radiation doses over longer times in a relatively inconvenient acquisition procedure and high cost compared to $\mathrm{CBCT}^{(11)}$.

In the present study also, comparison between male and female groups showed that the highest mean value was found in (Group B/ Males) group except for left gonial angle was higher in (Group A/ Females). This was a highly statistically significant $(\mathrm{p}<0.0001)$ in Bicondylar breadth, Bicoroniod breadth, bigonial width, Rt mental index, MML, Mandibular index, Rt height of mandible from mental foramen and statistically significant $(p<0.005)$ in both Rt gonial angle and Left height of mandible from mental foramen.

Another study for analyzing the sexual dimorphism in mandible by $3 \mathrm{D}-\mathrm{CT}{ }^{(11)}$ by taking the similar mandibular parameters in this study and was concluded that BIC-Br, G-angle, and minimal Ramus-L have significant sexual dimorphism with overall accuracy of $83.9 \%$; however, their study showed significant statistical difference with the G-angle, Ramus-L, G-G-L, BIC-Br, and CO-L $(P<$ 0.05 ) with overall accuracy of $84 \%$.

Also, in another study ${ }^{(20)}$ The aim was to achieve sexual determination using eight anthropometric measurements on mandibular CBCT images. Sample consisted of 120 CBCT scans, equally divided between sexes, collected from modern Egyptian population. For statistical analysis: intraclass correlation was used to evaluate intra- and inter-reviewers' reliability, analysis of variance to compare measurements with sex, logistic regression formulas were made to predict sex, and Pearson corelation coefficient was done to detect the relation between measurements and age variable. Four measurements showed significant difference (ramus length, body height at canine, bigonial breadth and distance from condyle to coronoid). The resultant percentage of accuracy was $85.8 \%$. The correct predictive accuracy for males was $86.7 \%$ and $85 \%$ for females.

In a previous study that was conducted on sex determination of human dry mandible using metrical parameters such as BG-Br, BIC-Br, and mandibular length and concluded that all these three parameters showed a significant gender difference ${ }^{(21)}$.

Also, in our study comparison between group A (females) and group B (males) in all mandibular measurements from age (20 to 30) year showed that the highest mean value was found in (Group $\mathrm{B} /$ Males) while the least mean value was found in (Group A/ Females) group. This was a highly statistically significant $(\mathrm{p}<0.0001)$ in Bicondylar breadth, Bicoroniod breadth, bigonial width, Rt 
height of mandible from mental foramen and statistically significant $(\mathrm{p}<0.005)$ in $\mathrm{Rt}$ mental index, MML, Rt gonial angle and Left height of mandible from mental foramen.

In the present study, comparison between group A (females) and group B (males) in all mandibular measurements but in different age group $(30<$ age to 40 year) was showed that the highest mean value was found in (Group B/ Males) except for gonial angle and left height of mandible from mental foramen was found higher in (Group A/ Females) group. This was a highly statistically significant $(\mathrm{p}<0.0001)$ in Bicondylar breadth, Bicoroniod breadth, Bigonial width, Mandibular index, MML, Rt mental index and statistically significant $(\mathrm{p}<0.005)$ in Lt mental index and Lt gonial angle.

And last we compared between group A (females) and group B (males) in all mandibular measurements in age from $40<$ age to 50 year and showed highest mean value was found in (Group B/ Males) while the least mean value was found in (Group A/ Females) group. This was a highly statistically significant $(\mathrm{p}<0.0001)$ in Bicondylar breadth, Bicoroniod breadth, Bigonial width, Mandibular index, MML, Rt height of mandible from mental foramen and statistically significant $(\mathrm{p}<0.005)$ in Rt mental index, Rt gonial angle and Lt height of mandible from mental foramen.

The accuracy rate in our study on Egyptian population was found to be $(83.7 \%)$ with a false rate of $(16.3 \%)$ in males and $(18.7 \%)$ in females. In another study ${ }^{(11)}$ founded an accuracy of $83.9 \%$ for sexual dimorphism (applied on six mandibular measurements). False identification of males was $16.4 \%$ versus $15.8 \%$ in females. Similarly, study ${ }^{(12)}$ was performed on same anthropometric measurements and found an accuracy of (89\%). Such fluctuations in results between our study and the other studies were due to difference in populations, observers, imaging techniques and software programs.

Obtaining results using maxillary sinus analysis by another study ${ }^{(16)}$ had achieved an accuracy rate of $73.9 \%$ in sexual dimorphism. In 2012, study ${ }^{(17)}$ was detected the reproducibility of the foramen magnum and other skeletal measurements in sexual dimorphism and found an accuracy rate of $90.7 \%$ for males and $73.3 \%$ for females.

\section{CONCLUSION}

It was concluded that mandible can be considered a valuable tool in gender determination since it possesses resistance to damage and disintegration processes. We found that the mandibular measurement using 3D-CT is reliable for the sex determination. With the availability of advanced imaging methods, forensic dentistry practitioner can successfully and accurately identify the sex of an unknown individual.

\section{REFERENCES}

1. Ilguy D, Ilguy M, Ersan N, Dolekoglu S, Fisekcioglu E. Measurements of foramen magnum and mandible in relation to sex using CBCT. J. Forensic Sci 2014; 59:601-5.

2. Kirk N, Wood R, Goldstein M. Skeletal identification using the frontal sinus region: a retrospective study of 39 cases. J. Forensic Sci 2002; 47: 318-23.

3. Patel S. New dimensions in endodontic imaging: Part 2 Cone beam computed tomography. Int Endod J. 2009; 42:463-75.

4. Miracle A, Mukherji S. Cone beam CT of the head and neck, part 2: clinical applications. American J. of neuroradiology. 2009; 30:1285-92.

5. Jaju PP, Jaju SP. Clinical utility of dental cone-beam computed tomography current perspectives. Clinical, cosmetic and investigational dentistry. 2014; 6:29.

6. Lee K-M, Lee W-J, Cho J-H, Hwang H-S. Threedimensional prediction of the nose for facial reconstruction using cone-beam computed tomography. Forensic Sci Int. 2014; 236:194. e1-. e5.

7. Marques J, Musse J, Caetano C, Corte-Real F, Corte-Real T. Analysis of Bite Marks in Foodstuffs by Computed Tomography (Cone Beam CT)-3D Reconstruction. J. of Forensic Odonto-Stomatology. 2013;31.

8. Star H, Thevissen P, Jacobs R, Fieuws S, Solheim T, Willems G. Human dental age estimation by calculation of pulp-tooth volume ratios yielded on clinically acquired 
cone beam computed tomography images of monoarticular teeth. Journal of forensic sciences. 2011;56(s1).

9. Marques JAM, Musse JdO, Gois BC, Galvão LCC, Paranhos LR. Cone-beam computed tomography analysis of the frontal sinus in forensic investigation. Int J Morphol. 2014; 32:660-5.

10. Gamba TDO, Alves MC, Haiter-Neto F. 3.1. Mandibular sexual J Forensic Radiology and Imaging. 2014; 2:104

11. Kharoshah MAA, Almadani O, Ghaleb SS, Zaki MK, Fattah YAA. Sexual dimorphism of the mandible in a modern African population. J Forensic Leg Med. 2010; 17:213-5.

12. Gamba T de O, Alves MC, Haiter-Neto F. Analysis of sexual dimorphism by locating the mandibular canal in images of cone-beam computed tomography. J Forensic Radiol Imaging. 2014; 2:72-6.

13. Naeem A, Nadia K, Saluja SA, Taseer B, Akhtar H. Evaluation of gender by measuring the size of maxillary sinus using computed tomographic scan in Indian population. J. of int. oral health. 2015; 7:88.

14. Iscan MY. Global forensic anthropology in the 21 st century. Forensic science international. Ireland; 2001; 117:1-6.
15. Saini V, Srivastava R, Rai RK, Shamal SN, Singh TB, Tripathi SK. Mandibular ramus: an indicator for sex in fragmentary mandible. J Forensic Sci. 2011 Jan;56 Suppl 1: S13-6.

16. Bush PJ, Bush MA. The next level in victim identification. Materials properties as an aid in victim identification. Forensic Dent Evid. 2011;55-72.

17. Marques JAM, Musse $\mathrm{J}$ de $\mathrm{O}$, Gois BC, Galvão LCC, Paranhos LR. Cone-beam Computed Tomography Analysis of the Frontal Sinus in Forensic Investigation. Int J Morphol. 2014; 32:660-5.

18. Payne-James J, Jones R, Karch SB, Manlove J. Simpson's Forensic Medicine. 2011;

19. Holland TD. Use of the cranial base in the identification of fire victims. J Forensic Sci. 1989 Mar; 34:458-60.

20. Mona Mahmoud Abu El-fotouh,Fatma Mostafa El-badawy, Ehab Samir Ali Abu El-ola El-nemr. Sex Determination of the Egyptian Population Using Mandibular CBCT Scans. Int. J. of Novel Research in Life Sci. 2018; 5:1-7.

21. Vinay G, Gowri SR, Anbalagan J. Sex determination of human mandible using metrical parameters. J Clin Diagn Res 2013; 7:2671-3. 